Dominik Mirostaw Piotrowski

Biblioteka Uniwersytecka w Toruniu

Uniwersytet Mikołaja Kopernika w Toruniu e-mail: dpi@umk.pl

\title{
IV Konferencja DARIAH-PL. Humanistyka cyfrowa a instytucje dziedzictwa (Toruń, 16-17 listopada 2017 r.)
}

DOI: http://dx.doi.org/10.12775/TSB.2018.008

STRESZCZENIE: W listopadzie 2017 r. w Bibliotece Głównej Uniwersytetu Mikołaja Kopernika w Toruniu odbyła się IV Konferencja Konsorcjum Naukowego DARIAH-PL. Jej tematem przewodnim była „Humanistyka cyfrowa a instytucje dziedzictwa”. Artykuł omawia podstawowe założenia konferencji oraz charakteryzuje poszczególne referaty.

SŁowA KLUCzowe: DARIAH-PL, humanistyka cyfrowa, dziedzictwo kulturowe, instytucje nauki, instytucje dziedzictwa, GLAM, konferencja, sprawozdanie

Dodczas dwudniowej konferencji, w czterech sesjach wygłoszonych zostało jedenaście referatów pierwszego dnia oraz dziewięć następnego. Pierwszego dnia odbyło się także posiedzenie Rady Konsorcjum Naukowego DARIAH-PL oraz debata. Wstępnie wszystkich uczestników powitała mgr Bożena Bednarek-Michalska, po czym oddała głos Prorektor ds. Ekonomicznych i Rozwoju prof. dr hab. Danucie Dziawgo, która już oficjalnie w imieniu władz rektorskich przywitała wszystkich przybyłych, podziękowała organizatorom, a także wyraziła obawy związane ze słabnącymi możliwościami finansowania humanistyki cyfrowej ze strony 
Ministerstwa Nauki i Szkolnictwa Wyższego. Następnie głos zabrał Prodziekan ds. Współpracy z Otoczeniem Zewnętrznym, dr Jacek Rakoczy, który w imieniu Wydziału Nauk Historycznych Uniwersytetu Mikołaja Kopernika w Toruniu powitał zgromadzonych, a w szczególności członków Rady Konsorcjum Naukowego DARIAH-PL, podziękował komitetowi organizacyjnemu, a także, mimo problemu jaki zasygnalizowała przedmówczyni, zadeklarował wsparcie dla badaczy oraz idei humanistyki cyfrowej. Prodziekan dr Jacek Rakoczy wyraził również nadzieję, że podczas obrad konferencyjnych oraz posiedzenia Rady Konsorcjum uda się „wypracować formułę” rozwoju humanistyki cyfrowej w kolejnych latach. Jako trzeci głos zabrał Przewodniczący Rady Konsorcjum Naukowego DARIAH-PL, prof. dr hab. Aleksander Bursche z Instytutu Archeologii Uniwersytetu Warszawskiego, który rozpoczął optymistycznym akcentem, iż można się spodziewać, że wysoki priorytet finansowania humanistyki cyfrowej będzie jednak w przyszłości utrzymany. Przewodniczący Rady Konsorcjum podziękował gospodarzom oraz organizatorom, a także wskazał na dobre praktyki współpracy instytucji kultury i dziedzictwa oraz nauki na przykładzie portalu Portable Antiquities Scheme (celem portalu jest społecznościowe rejestrowanie „źródeł ruchomych”), z którego dane i obiekty posłużyły do opracowania wielu prac naukowych oraz realizacji różnorodnych projektów. Profesor Aleksander Bursche na zakończenie postawił tezę, że współpraca przebiega wzorowo wówczas, kiedy dyrektorami instytucji kultury są wybitni naukowcy.

Profesor Aleksander Bursche był także moderatorem pierwszej sesji, poświęconej współpracy naukowców z instytucjami dziedzictwa oraz otoczeniu prawnemu. W sesji tej zaprezentowano 6 referatów, a otworzył ją referat pt. Pomosty!, przedstawiony przez dr Katarzynę Sztop-Rutkowską z Uniwersytetu w Białymstoku i Fundacji SocLab oraz mgr. Marcina Kozińskiego z Muzeum Wojska w Białymstoku. Referat dotyczył współpracy pomiędzy instytucjami kultury a „otoczeniem uniwersytetu i naukowcami” i podzielony został na dwie części. Pierwsza część zaprezentowana przez dr Katarzynę Sztop-Rutkowską miała charakter teoretyczny i dotyczyła tzw. „trzeciej misji” uniwersytetu, polegającej na tworzeniu relacji z otoczeniem społecznym. Autorka zauważyła, że jest to bardzo „ważna i istotna” misja, zwłaszcza w kontekście popularyzacji nauki, ale także edukacji, wdrażania wyników badań i komercjalizacji wiedzy. Jednakże na przeszkodzie w jej realizacji stają różnego typu ba- 
riery i problemy, wynikające z „niedocenienia tej działalności przy ocenie naukowców i całych jednostek” oraz „swoistej kultury organizacyjnej”. Druga część, przedstawiona przez mgr. Marcina Kozińskiego, zawierała studium przypadku pt. Ścieżki 3Dostępu, który stanowił interdyscyplinarny projekt opierający się na współpracy pomiędzy Muzeum Wojska w Białymstoku oraz Wydziałem Architektury Politechniki Białostockiej. Projekt początkowo polegał na skanowaniu muzealnych eksponatów, a następnie ich druku w technologii 3D w celu przygotowania ścieżek edukacyjnych. Wnioskiem końcowym obu części było stwierdzenie, że zarówno Uniwersytet w Białymstoku, jak i Muzeum Wojska Polskiego działają odrębnie, a stała współpraca tychże instytucji niestety nie wpisuje się w ich działalność.

Kolejny referat pt. Dokumentacja kultury a cyfrowe zasoby archiwalne. Przypadek Polskiej Bibliografii Literackiej i archiwum Telewizji Polskiej, autorstwa dr. Tomasza Umerle, mgr Beaty Koper oraz mgr. Cezarego Rosińskiego z Instytutu Badań Literackich Polskiej Akademii Nauk, wygłosili dr Tomasz Umerle oraz mgr Cezary Rosiński. Wystąpienie dotyczyło zastosowania archiwalnych zasobów wewnętrznej bazy danych Ośrodka Dokumentacji i Zbiorów Programowych Telewizji Polskiej przez twórców Polskiej Bibliografii Literackiej (dalej: PBL). Referenci opowiedzieli o swoich spostrzeżeniach i doświadczeniach, związanych z pozyskiwaniem cyfrowych (telewizyjnych) metadanych i współpracy z archiwum Telewizji Polskiej (dalej: TVP) w kontekście tworzenia i rozwoju PBL. Podczas przejmowania metadanych z TVP, napotkano na różnego typu problemy i wyzwania, związane z czyszczeniem i strukturalizacją danych czy też odmiennym spojrzeniem na metadane. Na zakończenie prelegenci odwołali się do postulatu otwartości metadanych, a także ich standaryzacji, jako ważnego czynnika umożliwiającego efektywny rozwój narzędzi oraz wzbogacanie elektronicznych zasobów kultury.

Trzeci referat pt. Współpraca archeologów z bydgoskiego muzeum ze światem nauki zaprezentowali mgr Jolanta Szałkowska-Łoś oraz mgr Józef Łoś. Autorzy referatu zasygnalizowali, że na przestrzeni ostatnich siedmiu lat zrealizowano trzy projekty. Pierwszy z nich, przy współpracy Muzeum Okręgowego w Bydgoszczy oraz Uniwersytetu Mikołaja Kopernika w Toruniu (dalej: UMK), obejmował prace z zakresu archeologii (oraz konserwatorstwa) nad bydgoskim grodziskiem. Wyniki zaprezentowano w formie ekspozycji muzealnych, zarówno tradycyjnych, jak i multimedialnych. 
Przyczyniło się to do popularyzacji wyników badań wśród odbiorców wystawy. Kolejny projekt naukowo-badawczy dotyczył wykopalisk archeologicznych na terenie krainy historycznej Krajny. W projekcie brali udział badacze reprezentujący różne dziedziny, a jego wynikiem było poszerzenie wiedzy z zakresu prehistorii okolicy Zakrzewskiej Osady, interdyscyplinarna publikacja naukowa oraz ekspozycja muzealna i witryna www. Trzecim projektem, w którym brali udział naukowcy oraz muzealnicy, była ekspozycja łącząca elementy tradycyjne i multimedialne, prezentująca prehistorię Bydgoszczy i okolic. Referenci zaznaczyli, że w ekspozycjach, oprócz technik multimedialnych (oraz rozszerzonej rzeczywistości), duży nacisk położony został na wiedzę merytoryczną uzyskaną z badań oraz edukację. Dzięki współpracy z naukowcami z UMK oraz Uniwersytetu im. Adama Mickiewicza w Poznaniu, a także firmami z sektora IT, możliwe stało się tworzenie bogatych i cennych ekspozycji muzealnych.

Czwarty referat pt. Muzeum Narodowe w Warszawie a Humanistyka Cyfrowa wygłosił mgr Mikołaj Machowski z Muzeum Narodowego w Warszawie. Referent utyskiwał, że humanistyka cyfrowa w Muzeum Narodowym w Warszawie nie funkcjonuje, tłumacząc tę kwestię w kontekście różnego typu działań Muzeum Narodowego, w tym udostępniania treści i ponownego użycia, a także podejścia naukowców do zasobów muzealnych oraz muzealników do humanistyki cyfrowej. Referent postrzegał omawiane zagadnienie nieco pesymistycznie.

Następny referat pt. $O$ potrzebie refleksji badawczej nad digitalizacja zasobów dziedzictwa kulturowego - przypadek Wirtualnych Muzeów Małopolski, autorstwa mgr Kingi Kołodziejskiej z Małopolskiego Instytutu Kultury w Krakowie, dotyczył współpracy Instytutu z instytucjami dziedzictwa oraz instytucjami naukowymi podczas realizacji projektu Wirtualne Muzea Małopolski (dalej: WMM). Celem projektu WMM jest „zachowanie dziedzictwa kulturowego Małopolski w formie cyfrowej i udostępnianie go szerokiemu gronu odbiorców". Istotną kwestią w rozwoju WMM była współpraca z naukowcami z Instytutu Filozofii i Socjologii Uniwersytetu Pedagogicznego im. KEN w Krakowie, w celu zweryfikowania, czy tworzenie cyfrowych zasobów wprowadza „nową jakość w odbiorze dziedzictwa kulturowego” oraz czy zastosowanie nowoczesnych technologii wpływa na zrozumienie dziedzictwa kulturowego. Wynikiem współpracy był projekt Cyfrowe praktyki i strategie upowszechniania i odbioru dziedzictwa kulturowego w Polsce w latach 2004-2014. Projekt 
zakończył się przygotowaniem raportu, który zawiera wskazania dotyczące głównych nurtów upowszechniania i odbioru zasobów dziedzictwa w internecie oraz wytyczne dla Ministerstwa Kultury i Dziedzictwa Narodowego oraz instytucji kultury (i nie tylko) w zakresie finansowania, promowania i udostępniania dziedzictwa kulturowego $\mathrm{w}$ formacie elektronicznym. Na zakończenie prelegentka wyraziła swoje wątpliwości i postulaty, dotyczące konieczności dalszych interdyscyplinarnych badań oraz współpracy badaczy z osobami odpowiedzialnymi za procesy ucyfrowienia zasobów.

Ostatni referat w pierwszej sesji, pt. Realizacja ustawy o ponownym wykorzystaniu informacji sektora publicznego w instytucjach publicznych - raport na pierwsze urodziny, autorstwa mgr Natalii Mileszyk z Fundacji Centrum Cyfrowe oraz mgr Magdaleny Siwanowicz z fundacji e-Państwo, miał na celu odpowiedzieć na pytanie, jak w rzeczywistości wygląda funkcjonowanie ustawy o reuse. Referentki omówiły założenia ustawy, scharakteryzowały różnego typu dane publiczne oraz możliwości ich użycia, a także wskazały na potencjał, jaki stwarza ponowne wykorzystanie dostępnych danych. Autorki postawiły również pytanie, jak można zwiększyć wykorzystanie danych. Odpowiedzią jest właśnie ustawa o reuse, jednak jak się okazuje, wcale nie przyczyniła się ona do zwiększenia ponownego wykorzystania danych. Według referentek, głównym powodem była znikoma wiedza (lub wręcz jej brak) na temat ponownego wykorzystywania danych.

Drugą sesję, poświęconą usługom i produktom wspierającym wzajemną współpracę instytucji nauki i dziedzictwa, otworzył jej moderator - dr Piotr Malak. W sesji tej zaprezentowanych zostało 5 referatów. Pierwszy przedstawiony został referat pt. Wyszukiwanie zaawansowane $w$ bibliograficznych bazach danych jako narzędzie badawcze, autorstwa mgr. inż. Marcina Werli, mgr inż. Ewy Śniegowskiej, mgr Karoliny Bohdanowicz oraz mgr. Arkadiusza Margrafa z Działu Bibliotek Cyfrowych i Platform Wiedzy Poznańskiego Centrum Superkomputerowo-Sieciowego. Temat zreferował mgr inż. Marcin Werla, który zaprezentował wybrane elementy i możliwości interfejsu zastosowanego w nowej odsłonie bazy $P B L$. Interfejs zaprojektowany został w oparciu o analizę potencjału, jaki oferują interfejsy wyszukiwania zaawansowanego w różnego typu katalogach i bazach bibliograficznych, jak też potrzeb informacyjnych użytkowników $P B L$. Na zakończenie swojego wystąpienia referent wy- 
raził przekonanie, że dzięki nowemu systemowi wyszukiwania uda się połączyć bogate zasoby bazy $P B L$ z możliwością jej eksploracji z pomocą użytecznego i przyjaznego interfejsu.

Kolejny referat autorstwa dr. Dominika Mirosława Piotrowskiego z Biblioteki Uniwersyteckiej w Toruniu nosił tytuł Curatescape - dostarczanie treści historycznych opartych na lokalizacji - oprogramowanie dla humanistów i instytucji dziedzictwa. Referent zaprezentował potencjał, jaki oferuje otwartoźródłowe oprogramowanie Curatescape (stanowiące zestaw wtyczek oraz motyw graficzny dla otwartego systemu Omeka) w kontekście tworzenia mobilnych projektów interpretacyjnych na przykładzie projektu Cleveland Historical. Dominik M. Piotrowski ukazał możliwości, jakie humanistyka cyfrowa oferuje instytucjom dydaktycznym, organizacjom regionalnym oraz instytucjom GLAM, a także wskazał na potrzebę współpracy badaczy i pracowników instytucji GLAM, członków lokalnych społeczności, nauczycieli oraz pasjonatów w celu stworzenia wysokiej jakości treści historycznych opartych na geolokalizacji.

Kolejny referat pt. Archiwalne bazy danych $w$ warsztacie historyka zaprezentowała dr Ewa Rosowska z Naczelnej Dyrekcji Archiwów Państwowych w Warszawie. Referentka przedstawiła historię komputeryzacji i informatyzacji polskich archiwów oraz wskazała na archiwalne bazy danych oraz serwis wyszukiwawczy szukajwarchiwach.pl (wraz z jego statystykami), które stanowią pomoc w pracy badaczy z zakresu historii. Ewa Rosowska zauważyła, że dostępność elektronicznych źródeł informacji archiwalnej może np. skrócić czas realizacji kwerend czy umożliwić przeprowadzenie badań w różnych zasobach, jednak ostatecznie badacze muszą sami zanalizować badane materiały archiwalne. Na zakończenie autorka postawiła kilka otwartych pytań, dotyczących dalszej digitalizacji i zarządzania zasobami archiwalnymi w formie elektronicznej.

Czwarty referat pt. Serwis tematyczny FBC Czasopisma jako przykład usług humanistyki cyfrowej zaprezentował mgr inż. Marcin Werla - współautor referatu wraz z mgr inż. Aleksandrą Nowak z Poznańskiego Centrum Superkomputerowo-Sieciowego (dalej: PCSS). Intencją referatu było przedstawienie różnych etapów ( $w$ tym badań użytkowników bibliotek cyfrowych) oraz problemów związanych z powstawaniem i projektowaniem serwisu FBC Czasopisma. Serwis agreguje metadane obiektów dostępnych online z bibliotek cyfrowych, prowadzonych przez różne instytucje kultury oraz umożliwia przeszukiwanie zgromadzonych charakterystyk i odsyła- 
nie do konkretnych pozycji. Na zakończenie swojego wystąpienia Marcin Werla zademonstrował interfejs oraz funkcjonalności serwisu za pomocą scenariusza obejmującego przykładowe wyszukiwanie.

Ostatni referat pt. Wykorzystanie zasobów bibliograficznych przez instytucje kultury (na przykładzie systemu iSyblislaw), autorstwa dr. Pawła Kowalskiego, dr Zofii Rudnik-Karwatowej, mgr. Jakuba Banasiaka oraz dr. Marcina Fastyna z Instytutu Slawistyki Polskiej Akademii Nauk w Warszawie, zaprezentowali dr Paweł Kowalski oraz dr Marcin Fastyn. Referat miał na celu prezentację możliwości zastosowania systemu iSyblislaw w bibliotekach i wydawnictwach naukowych. Referenci wskazali na sieć powiązań w środowisku cyfrowym oraz „model upowszechniania i przepływu wiedzy" między tradycyjnym drukowanym dokumentem, bazą bibliograficzną, wydawnictwem naukowym, a zainteresowaną danym tematem społecznością. W podsumowaniu zasygnalizowano wiele korzyści związanych z integracją zasobów wydawnictwa i bazy bibliograficznej, przejawiających się m.in. w poszerzeniu grupy odbiorców informacji czy efektywniejszym popularyzowaniu wiedzy.

Pod koniec drugiej sesji odbyła się dyskusja (dotycząca dwóch pierwszych sesji), którą otworzyła mgr Bożena Bednarek-Michalska wraz z dr. Piotrem Malakiem. Podczas dyskusji duże zainteresowanie wzbudził temat dotyczący ustawy o reuse oraz możliwości użycia nie tylko samych metadanych, ale też zdigitalizowanych obiektów. Kolejnymi omawianymi kwestiami były: opieka archiwów państwowych nad archiwami społecznymi oraz problem efektywnego i bezpiecznego zarządzania dużymi zbiorami informacji archiwalnej. Na zakończenie dr Agnieszka Rosa poinformowała autorów referatów o możliwości publikacji tekstów w otwartym recenzowanym czasopiśmie „Archiwa - Kancelarie Zbiory". Po dyskusji odbyło się posiedzenie Rady Konsorcjum Naukowego DARIAH-PL. Wieczorem w Centrum Sztuki Współczesnej w Toruniu miała miejsce debata $O$ barierach we współpracy nauki z instytucjami dziedzictwa w zakresie realizacji wspólnych przedsięwzięć cyfrowych, której moderatorem był Przewodniczący Zespołu ds. DARIAH, mgr Dominik Purchała z Laboratorium Cyfrowego Humanistyki Uniwersytetu Warszawskiego (dalej: LCH UW) oraz Wydziału Historycznego UW. W debacie udział wzięli: prof. dr hab. Aleksander Bursche, mgr Dorota Szkodzińska z Muzeum Historii Polski, dr hab. Dariusz Brzostek z Katedry Kulturoznawstwa UMK, mgr Małgorzata Baka z Zakładu Muzealnictwa UMK oraz 
mgr inż. Marcin Werla. Pierwszy dzień obrad zakończył się spotkaniem towarzyskim w kawiarni cafe pARTer, znajdującej się w Centrum Sztuki Współczesnej w Toruniu.

Drugi dzień konferencji podzielony został na dwie kolejne sesje. Sesja trzecia (pierwsza drugiego dnia obrad), w której zaprezentowano 5 referatów, poświęcona została projektom realizowanym we współpracy instytucji nauki i dziedzictwa. Sesję poprowadził dr hab. Andrzej Radomski z Instytutu Kulturoznawstwa Uniwersytetu Marii Curie-Skłodowskiej w Lublinie. Pierwszy referat nosił tytuł Jak frustracja etnografów zmieniła Wikipedię - \#EtnoWiki jako przykład dobrej praktyki Open GLAM i przedstawiony został przez mgr Klarę Sielicką-Baryłkę z Państwowego Muzeum Etnograficznego w Warszawie (dalej: PME). Referentka zaprezentowała rys historyczny oraz wnioski płynące z projektów etnograficznych, realizowanych przy współpracy z Wikipedią oraz Wikimedia Foundation. Projekty te polegały w szczególności na wspólnych wyjazdach terenowych pracowników PME oraz wikipedystów w celu stworzenia dokumentacji, służącej następnie do budowy haseł Wikipedii. Kończąc swoje wystąpienie mgr Klara Sielicka-Baryłka postulowała, aby bliżej przyjrzeć się potencjałowi, jaki oferuje serwis Wikidata, za pomocą którego można tworzyć metadane rekordów związanych m.in. z muzeami, czy aplikacji Crotos, umożliwiającej przeszukiwanie i wyświetlanie dzieł sztuki, opartych na Wikidata i Wikimedia Commons.

Następnie moderator wywołał dr hab. Matyldę Włodarczyk z Wydziału Anglistyki Uniwersytetu im. Adama Mickiewicza w Poznaniu (dalej: WA UAM) oraz dr. Michała Kozaka z Poznańskiego Centrum Superkomputerowo-Sieciowego, z referatem pt. Wielojęzyczność $w$ średniowiecznej Wielkopolsce: Digitalizacja Wielkopolskich Rot Sądowych (projekt ROThA). Referat zaprezentował dr Michał Kozak, który omówił genezę i założenia projektu ROThA. Koncepcja narodziła się na WA UAM i tam też powstał zespół, który kieruje projektem. Infrastrukturę informatyczną w postaci bazy danych, archiwum cyfrowego, portalu i wyszukiwarki dostarcza PCSS, a zawartość repozytorium, w formie zdjęć rękopisów, Archiwum Państwowe w Poznaniu. Projekt opiera się na 5 tomach publikacji pt. Wielkopolskie roty sq̨dowe XIV-XV wieku, a szerokie pole badawcze otwiera zapis dokumentów w sposób dwujęzyczny, mianowicie po łacinie oraz po polsku. W cyfrowym repozytorium, oprócz fotografii rot, znajdować będą się także transkrypcje dyplomatyczne przysiąg sądowych, tłuma- 
czenia oraz dodatkowa warstwa analityczna bazująca na tagach. Całość stanowić będzie użyteczny i wartościowy zasób cyfrowy, skierowany do historyków i językoznawców.

Kolejny referat pt. „Zapisy terroru” - cyfrowe archiwum w kulturze pamięci zaprezentował mgr Krzysztof Wiśniewski z Ośrodka Badań nad Totalitaryzmami im. Witolda Pileckiego w Warszawie. Wystąpienie dotyczyło portalu Zapisy Terroru, który wpisuje się w „kulturę pamięci” i stanowi cyfrowe archiwum świadectw zawierających „relacje obywateli polskich, którzy podczas II wojny światowej doświadczyli cierpienia ze strony dwóch totalitaryzmów: niemieckiego i sowieckiego". Referent (i zarazem koordynator projektu Zapisy Terroru) wskazał na pochodzenie źródeł (zeznań) znajdujących się w archiwum oraz zaprezentował bogate funkcjonalności portalu, który dzięki współpracy z PCSS posadowiony jest na systemie dLibra.

Następnymi prelegentkami, które przeniosły słuchaczy w o wiele lżejszą tematykę, były: mgr Karina Rojek z Instytutu Kultury Miejskiej w Gdańsku oraz mgr Marta Pawlik-Flisikowska z Biblioteki Gdańskiej Polskiej Akademii Nauk (dalej: PG PAN) z referatem pt. PANkreator wspólny projekt cyfrowy - PAN Biblioteki Gdańskiej, Instytutu Kultury Miejskiej oraz społeczności Koduj dla Polski. Referentki omówiły okoliczności powstania i założenia projektu PANkreator. Ma on na celu promocję i popularyzację zdigitalizowanych zbiorów BG PAN, znajdujących się w Pomorskiej Bibliotece Cyfrowej. Serwis PANkreator zawiera kolekcję animowanych gifów, które mogą posłużyć do wysyłania dźwiękowych pocztówek oraz prowadzony przez bibliotekarzy blog, na którym publikowane są wpisy dotyczące zbiorów bibliotecznych, z jakich tworzone są animowane gify. Jak podkreślały referentki, projekt jest doskonałym przykładem współpracy między naukowcami, pracownikami instytucji kultury, informatykami i humanistami, którzy uczą się jedni od drugich, a ich wiedza i doświadczenia uzupełniają się.

Kolejny referat pt. Wirtualny Gross Sobrost, którego autorami byli mgr Marta Bura i mgr Janusz Janowski z Pracowni Skanerów 3D LCH UW oraz mgr Maciej Tarkowski z Reconstruction.pl, zaprezentowała mgr Marta Bura. Referentka wprowadziła uczestników konferencji do projektu, który wpisuje się we wspomnianą wcześniej trzecią misję uczelni, polegającą na współpracy z otoczeniem oraz instytucjami dziedzictwa. Zamierzeniem projektu było powiązanie różnego typu metod badawczych, polegających 
na skanowaniu naziemnym, mobilnym i lotniczym oraz modelowania budynków na podstawie archiwalnych zdjęć z 1917 r. w celu „ocalenia od zapomnienia", utworzenia obszernej dokumentacji 3D oraz wirtualnej rekonstrukcji przepięknej wsi mazurskiej Zabrost Wielki (Gross Sobrost). Po wygłoszeniu referatu moderator otworzył dyskusję, w której pytania dotyczyły głównie rekonstrukcji 3D wsi Zabrost Wielki, a także projektów Zapisy terroru, PANkreator i \#EtnoWiki. Na zakończenie dyskusji dr hab. Andrzej Radomski zachęcił do publikacji wyników projektów, niekoniecznie w formie artykułów, ale raczej w postaci wizualizacji, chociażby w periodyku naukowym „Medialica. Studia Multimedialne z Humanistyki”.

Przewodniczącą czwartej, ostatniej sesji poświęconej obszarom badawczym humanistyki cyfrowej potencjalnie przydatnym instytucjom dziedzictwa, była mgr Bożena Bednarek-Michalska. W sesji tej wygłoszone zostały cztery referaty. Pierwszy, zatytułowany Gromadzenie i udostępnianie danych badawczych w polskich czasopismach o tematyce historycznej, zaprezentował dr Adam Jachimczyk z Instytutu Dziennikarstwa i Informacji Uniwersytetu Jana Kochanowskiego w Kielcach. Autor na wstępie zasygnalizował problemy związane z publikacją i udostępnianiem surowych danych badawczych w humanistyce, a następnie zaprezentował wyniki analizy, której głównym celem było zweryfikowanie, czy polskie czasopisma naukowe z zakresu historii posiadają własną politykę pracy z danymi badawczymi. W wyniku przeprowadzonych prac można było sformułować wnioski, że rozpatrywane periodyki nie dostrzegają problemu optymalnego udostępniania danych badawczych, a ich polityka (oraz świadomość) w tym zakresie pozostawia wiele do życzenia.

Kolejny referat pt. Widzialna i niewidzialna architektura informacjidostępność i użyteczność zasobów cyfrowych zgodnie z zasadami WCAG 2.0 wygłosiła dr Izabela Mrochen z Instytutu Języków Romańskich i Translatoryki Uniwersytetu Śląskiego w Katowicach. Referentka przedstawiła pokrótce kryteria tworzenia stron i treści internetowych przyjaznych dla użytkowników oraz problemy związane z postrzeganiem cyfrowej zawartości, a także wprowadziła uczestników w zagadnienia związane z wytycznymi dostępności treści internetowych. Podczas prezentacji dr Izabela Mrochen skupiła się tylko na wybranym zagadnieniu związanym z dostępnością, mianowicie atrybucie alt, umożliwiającym opatrywanie obrazów tekstem alternatywnym. Na zakończenie referentka wykazała i skomentowała złe praktyki dostępności zastosowane w witry- 
nie Filmowa Encyklopedia Powstań Śląskich, a także wysunęła postulaty, aby już na etapie projektowania, a następnie realizacji projektu, włączyć do prac zespół ds. dostępności i stale współpracować z użytkownikami $\mathrm{z}$ różnego typu dysfunkcjami. Referat wywołał ciekawe komentarze z sali, związane m.in. z kształceniem studentów oraz zwiększaniem świadomości różnych grup (np. redaktorów Wikipedii) w zakresie tworzenia dostępnych treści internetowych.

Następnym prelegentem wywołanym przez mgr Bożenę Bednarek-Michalską był mgr Bartłomiej Konpa, doktorant z Wydziału Nauk Historycznych UMK, z referatem pt. Archiwa internetu jako nowe bazy źródłowe. Referent wprowadził słuchaczy do problematyki związanej z archiwizacją internetu, podkreślił znaczenie tego typu przedsięwzięć oraz scharakteryzował wybrane inicjatywy i narzędzia do archiwizacji zasobów webu w kontekście długoterminowego przechowywania i dostępu do danych w celach badawczych. Po wystąpieniu wywiązała się dyskusja, której uczestnicy wskazywali głównie na problemy natury prawnej związane $\mathrm{z}$ archiwizacją internetu.

Ostatni referat, zamykający sesję czwartą, pt. Potencjał wykorzystania metod humanistyki cyfrowej $w$ badaniach nad muzealnictwem. Projekt „Muzeum w polskiej kulturze pamięci (do 1918 r.): wczesne instytucje muzealne wobec muzeologii cyfrowej" autorstwa mgr Małgorzaty Baki i mgr Eweliny Bednarz z Zakładu Muzealnictwa UMK, wygłosiła mgr Małgorzata Baka. Prelegentka omówiła projekt badawczy Muzeum w polskiej kulturze pamięci (do 1918 r.)..., którego celem jest „analiza i kompleksowe badanie roli wczesnych muzeów” w kontekście „kształtowania szeroko pojętej tożsamości i pamięci kulturowej", integracja wiedzy na ten temat oraz utworzenie przestrzeni do dyskusji z wykorzystaniem narzędzi cyfrowych. Projekt de facto zrodził się z potrzeb zasygnalizowanych w środowisku muzealników i opiera się na połączeniu tradycyjnych metod badawczych z możliwościami, jakie oferuje humanistyka cyfrowa i technologie informacyjno-komunikacyjne. Dzięki utworzeniu specjalistycznego portalu Muzeum Pamięci (posadowionego na popularnym otwartym systemie zarządzania treścią WordPress), możliwe staje się przedstawienie kompletnego wizerunku badań, jak również rozszerzenie pola badawczego, zwiększenie wydajności prowadzonych prac badawczych oraz publikacja treści na wolnych licencjach. Na zakończenie swego wystąpienia mgr Małgorzata Baka podzieliła się z uczestnikami 
konferencji planami, związanymi z dalszym rozwojem projektu oraz rozwiązaniami, które w przyszłości mogą zaistnieć w portalu.

Na zakończenie drugiego i zarazem ostatniego dnia konferencji mgr Bożena Bednarek-Michalska dokonała podsumowania, w którym podkreśliła, że konferencja odbyła się ze względu na to, że UMK należy do Konsorcjum Naukowego DARIAH-PL, które z kolei przynależy do infrastruktury badawczej DARIAH-EU. Zadaniem tej sieci współpracy jest rozwój humanistyki cyfrowej, a dzięki organizacji konferencji w Toruniu, mogliśmy podjąć ważny temat współdziałania instytucji nauki z instytucjami dziedzictwa. Bożena Bednarek-Michalska zwróciła uwagę na logiczną strukturę konferencji, która wynikała z tematu przewodniego, dzięki czemu uczestnicy mogli zapoznać się z szerokim spektrum inicjatyw, jakie realizowane są na pograniczu obszarów działalności instytucji nauki oraz instytucji kultury. Współpraca ta układa się różnie, czasem wzorowo, a czasem pozostawia wiele do życzenia, generuje także różnego typu problemy, głównie są to kwestie natury prawnej lub finansowej. Następnie głos zabrał dr hab. Andrzej Radomski, który zwrócił uwagę na fakt, że niniejsza konferencja, w opozycji do wcześniejszych trzech konferencji DARIAH-PL, rozszerzyła swój zakres tematyczny o współpracę środowiska naukowego z instytucjami dziedzictwa. Toruńska konferencja dowiodła, że humanistykę cyfrową można uprawiać również poza murami uczelni, co stwarza doskonałe warunki do współpracy między badaczami oraz pracownikami instytucji dziedzictwa. Tezę tę zaakcentował także mgr Dominik Purchała z UW, który wyraził nadzieję, że współpraca ta będzie kontynuowana. Na zakończenie Bożena Bednarek-Michalska serdecznie podziękowała uczestnikom i zamknęła konferencję.

\section{Bibliografia}

„Humanistyka cyfrowa a instytucje dziedzictwa” - IV Konferencja DARIAH-PL: 16-17 listopada 2017: Biblioteka Uniwerstecka Uniwersytetu Mikołaja Kopernika w Toruń [online] [dostęp 14 lutego 2018]. Dostępny w World Wide Web: http://kpbc.umk.pl/dlibra/publication?id=185304

Dariah Theme 2017 „Cultural Heritage and Humanities Research” - Sciencesconf. org [online] [dostęp 14 lutego 2018]. Dostępny w World Wide Web: https:// dariahtheme2017.sciencesconf.org/ 
IV Konferencja DARIAH-PL [online] [dostęp 14 lutego 2018]. Dostępny w World Wide Web: https://www.youtube.com/watch?v=13BmDDFuMAI IV Konferencja DARIAH-PL [online] [dostęp 14 lutego 2018]. Dostępny w World Wide Web: https://www.youtube.com/watch?v=RcK0IHxe1Hs

Regulamin Rady Konsorcjum Naukowego DARIAH-PL [online] [dostęp 14 lutego 2018]. Dostępny w World Wide Web: http://dariah.pl/wp-content/uploads/2015/08/Regulamin-Rady-DARIAH-PL.pdf

Relacja i materiały z konferencji DARIAH-PL 2017 [online] [dostęp 14 lutego 2018]. Dostępny w World Wide Web: https://dariah.pl/relacja-i-materialy-z-konferencji-dariah-pl-2017/

Temat i cel konferencji - IV Konferencja DARIAH-PL [online] [dostęp 14 lutego 2018]. Dostępny w World Wide Web: http://2017.dariah.pl/

\section{4th DARIAH-PL Conference: Digital humanities and heritage institutions (Toruń, November 16-17, 2017)}

ABSTRACT: In November, 2017 in the Main Library of the Nicolaus Copernicus University in Torun, the 4th Conference of the Scientific Consortium DARIAH-PL took place. The main theme of the event was „Digital humanities and heritage institutions". The article discusses the basic topics of the conference and characterizes the individual papers.

KeYwORDS: DARIAH-PL, digital humanities, cultural heritage, science institutions, heritage institutions, GLAM, conference, report 